RESEARCH ARTICLE

\title{
Gene action and Combining Ability Studies Using line x Tester Analysis in Sunflower (Helianthus annuus L.)
}

\author{
Ghodekar V G ${ }^{1^{*}}$, Ghodke $M K^{2}$, Sargar $\mathbf{P ~ R}^{\mathbf{1}}$ and Dhakne V $\mathbf{R}^{3}$ \\ ${ }^{1 *}$ Department of Agricultural Botany, College of Agriculture, Latur. \\ ${ }^{2}$ Oilseed Research Station, Latur. \\ ${ }^{3}$ Department of Horticulture, College of Agriculture, Latur.
}

\begin{abstract}
The present investigation was aimed to study the combining ability and gene action in parents and hybrids of sunflower for seed yield and components traits. Six female lines were crossed with four male lines by Line $x$ Tester method, to obtain $24 \mathrm{~F}_{1} \mathrm{~s}$. Data were recorded on ten characters. Among the female parents CMS-108A, CMS-250A and CMS-207A were good general combiners for seed yield and other contributing traits. Among the male parents, IB-22, EC-178178, EC-601957 were identified as the best general combiners for seed yield and other yield contributing traits. The crosses showing high desirable SCA effect have involved one of the parents of high GCA effect and in turn, had high per se performance. The SCA effect of hybrids viz., CMS-207A x IB-22 and CMS-108A x GP-6-116 were highly significant for seed yield/plant ( $g$ ) and other component traits in a desirable direction, indicating that the high performance of these crosses is due to non-allelic gene action.Non-additive gene action is predominant for all the studied characters except days to 50\% flowering, plant height $(\mathrm{cm})$ and hull content (\%).
\end{abstract}

Keywords: Sunflower; Combining ability; Gene Action;GCA; SCA; Line; Tester.

\section{INTRODUCTION}

Sunflower (Helianthus annuus L. $2 n=34$ ), is an important oilseed crop in the world, belongs to the genus Helianthus and the family 'Asteraceae' (Compositae).It is also known as 'Surajmukhi' in Hindi, 'Suryaphul' in Marathi. It is native to southern parts of the USA and Mexico. Sunflower is the second most important oilseed crop globally after soybean because of its wide range of adaptability and high oil (40-50\%) and protein content (23\%). It can be grown successfully in different parts of the world due to its wide adaptability, photo-insensitive and thermo-insensitive nature.Several biometrical techniques have been developed to generate information on gene action and modeof inheritance of various characters, among which line $x$ tester analysis (Kempthorne, 1957) has been widely used for genetic analysis in a large number of crop plants. It is a very efficient technique for evaluating many inbreds for their combining ability and studying gene action controlling various characters to adopt an appropriate breeding strategy.

\section{MATERIALS AND METHODS}

The present investigation for combining ability studies in sunflower (Helianthus annuus L.) using
Line $x$ Tester mating design was conducted during kharif 2019-2020, at Oilseeds Research Station, Latur.The experimental material for the present study includedfour CMS lines as female parents and six restorers as male parents, whichwere crossed by Line $x$ Tester mating design to produce 24 new hybrids, in Rabi, 2018-19. Thehybrids were evaluated in Randomized Block Design with two replicationsfor combining ability in Kharif2019-20. Observations were recorded on five random but competitive plants for ten characters viz., days to 50 percent flowering, days to maturity, plant height $(\mathrm{cm})$, head diameter $(\mathrm{cm})$,seed filling (\%), hull content (\%), 100 seed weight (g),seed yield / plant (g),oil content (\%) and volume weight (g/100mL). Mean values were subjected to line $x$ tester analysis to estimate general combining ability (GCA) and specific combining ability (SCA) effects and their respective variances as per the method suggested by Kempthorne (1957)

\section{RESULT AND DISCUSSION}

The analysis of variance was worked out to assess the variation among the parental lines and crosses for ten characters. The significance was marked by applying F-test. The analysis of variance

$107 \mid 10-12$ | 1 
for ten characters consisting of replication mean square, treatment mean square, error mean square and critical differences at $5 \%$ and $1 \%$ is given in table 1 . The mean sum of squares due to treatments werehighly significant for all the characters under study. This indicates the existence of sufficient variability for yield and yield contributing characters in the material under study.

Table 1: Analysis of variance for parents and crosses for ten morphological traits in sunflower.

\begin{tabular}{|c|c|c|c|c|c|c|c|c|c|c|c|}
\hline $\begin{array}{l}\text { Source of } \\
\text { variation }\end{array}$ & d. $f$. & $\begin{array}{c}\text { Days to } \\
50 \% \\
\text { flowering }\end{array}$ & $\begin{array}{l}\text { Days to } \\
\text { maturity }\end{array}$ & $\begin{array}{l}\text { Plant height } \\
\text { (cm) }\end{array}$ & $\begin{array}{l}\text { Head } \\
\text { diameter } \\
(\mathbf{c m})\end{array}$ & $\begin{array}{c}\text { Seed filling } \\
(\%)\end{array}$ & $\begin{array}{c}\text { Hull } \\
\text { content } \\
(\%)\end{array}$ & $\begin{array}{l}100 \text { Seed } \\
\text { weight }(g)\end{array}$ & $\begin{array}{l}\text { Seed Yield } \\
\text { / plant (g) }\end{array}$ & $\begin{array}{c}\text { Oil } \\
\text { content } \\
(\%)\end{array}$ & $\begin{array}{l}\text { Volume weight } \\
(\mathrm{g} / 100 \mathrm{~mL})\end{array}$ \\
\hline Replication & 1 & 6.485 & 16.014 & 8.47 & 2.7 & 5.292 & 0.381 & 0.371 & 0.044 & 0.214 & 29.554 \\
\hline Treatment & 35 & $7.520 * *$ & $21.399 * *$ & $620.02 * *$ & $4.553 * *$ & $106.94 * *$ & 37.874 & $0.696 * *$ & 120.136 ** & $11.38 * *$ & $46.584 * *$ \\
\hline Parents & 9 & $7.755^{*}$ & $39.800 * *$ & $881.27 * *$ & $3.486 * *$ & $160.02 * *$ & 33.662 & $0.7801 * *$ & $40.051 * *$ & $21.98 * *$ & 11.71 \\
\hline CMS lines & 3 & 8.5 & $30.791 * *$ & $728.44 * *$ & 2.219 & $120.44 * *$ & 4.547 & $1.892 * *$ & $58.817 * *$ & $40.16 * *$ & 9.087 \\
\hline Tester & 5 & 6.933 & $49.483 * *$ & $1071.23 * *$ & $4.920 * *$ & $160.28 * *$ & 20.622 & $0.250 * *$ & $30.053 * *$ & $4.492 * *$ & 10.408 \\
\hline Crosses & 23 & $7.187 * *$ & $14.716 *$ & $263.68 * *$ & 1.84 & $12.396 * *$ & 32.717 & $0.5815 * *$ & $231.27 * *$ & $3.711 * *$ & $47.793 * *$ \\
\hline Line $\mathrm{x}$ Tester & 15 & 9.633 & 18.408 & $389.98 * *$ & 0.119 & $277.46 * *$ & $186.20 * *$ & 0.0891 & $33.739 * *$ & $54.91 * *$ & 26.096 \\
\hline $\begin{array}{l}\text { Parents v/s } \\
\text { Crosses }\end{array}$ & 1 & $13.078 *$ & 9.512 & $6464.61 * *$ & $76.56 * \star$ & $1803.97 * *$ & $194.41 * *$ & $2.603 * *$ & $1186.5^{\star *}$ & $92.51 * *$ & 332.64 ** \\
\hline Error & 35 & 2.9398 & 6.59 & 22.992 & 1.0875 & 14.093 & 21.821 & 0.0392 & 1.9188 & 0.7621 & 7.825 \\
\hline
\end{tabular}

**and* indicates significant at $1 \%$ and $5 \%$, respectively.

Generally, the parents with high per se may not transmit their superiority in their progenies. Hence, it is crucial to calculate the combining ability of parents forestimating their performance in the hybrids. Crosses were found to be significant for all traits except head diameter (cm) and hull content (\%). The significance of variance due to parents Vs crosses indicated the presence of heterosis in hybrids for all characters except days to maturity. Similar findings were also reported by Halaswamy et al. (2004) and RaviRana et al. (2004).
The magnitude of specific combining ability variances was larger than general combining ability variances for all the characters except days to $50 \%$ flowering, plant height, seed filling (\%) and hull content (\%). The ratio of ( $\delta 2 \mathrm{GCA} / \delta 2 \mathrm{SCA})$ was less than unity for almost all characters except days to $50 \%$ flowering, hull content, and plant height,indicating the predominance of non-additive gene action, which is in agreement with the results of Radhika et al. (2001).

Table 2: Estimates of general combining ability effects (GCA) of lines and testers for ten morphological traits.

\begin{tabular}{|c|c|c|c|c|c|c|c|c|c|c|}
\hline Characters & \begin{tabular}{|l|}
$\begin{array}{l}\text { Days to } 50 \\
\text { \% flowering }\end{array}$ \\
\end{tabular} & \begin{tabular}{|c|}
$\begin{array}{c}\text { Days to } \\
\text { maturity }\end{array}$ \\
\end{tabular} & $\begin{array}{c}\text { Plant } \\
\text { height }(\mathbf{c m})\end{array}$ & \begin{tabular}{|c|} 
Head \\
diameter $(\mathrm{cm})$
\end{tabular} & \begin{tabular}{|c|} 
Seed \\
filling (\%) \\
\end{tabular} & \begin{tabular}{|c|}
$\begin{array}{c}\text { Hull } \\
\text { content (g) }\end{array}$ \\
\end{tabular} & $\begin{array}{c}100-\text { Seed } \\
\text { weight (g) }\end{array}$ & \begin{tabular}{|c|}
$\begin{array}{c}\text { Seed Yield } \\
\text { plant (g) }\end{array}$ \\
\end{tabular} & $\begin{array}{c}\text { Oil content } \\
(\%)\end{array}$ & $\begin{array}{c}\text { Volume weight } \\
(\mathrm{g} / 100 \mathrm{ml})\end{array}$ \\
\hline CMS 108A & $-1.438 * *$ & 1.354 & $-14.916 * *$ & 0.53 & 1.821 & $4.290 * *$ & -0.112 & $3.893 * *$ & -0.003 & $3.113 * *$ \\
\hline CMS 250A & $1.063 *$ & $-2.313 * *$ & $8.276 * *$ & 0.519 & 0.633 & -1.552 & 0.024 & $-1.639 * *$ & -0.274 & 1.303 \\
\hline CMS 249A & -0.104 & 1.271 & 1.556 & $0.681 *$ & -2.097 & -2.71 & 0.079 & $-5.453 * *$ & $1.355 * *$ & $-1.672 *$ \\
\hline CMS 207A & 0.479 & -0.313 & $5.084 * *$ & -0.368 & -0.357 & -0.207 & 0.01 & $3.199 * *$ & $-1.078 * *$ & $-2.743 * *$ \\
\hline IB-22 R & -1.188 & 0.271 & -2.541 & 0.169 & -2.14 & -0.885 & -0.180 * & $2.548 * *$ & $0.298 * *$ & 1.264 \\
\hline EC-601957R & 0.313 & 0.146 & $-4.083 *$ & -0.232 & 1.158 & 1.665 & 0.037 & $-1.838 * *$ & 0.239 & $-3.516 * *$ \\
\hline EC-198075R & -0.313 & -0.854 & 0.834 & -0.075 & 0.659 & -1.198 & $0.326 * *$ & $-1.117 * *$ & $-1.178 * *$ & 0.359 \\
\hline EC-178178R & 0.563 & -0.354 & -0.878 & -0.148 & -1.155 & 1.927 & $-0.371 * *$ & $-2.745 * \star$ & $0.589 * *$ & $-3.599 * *$ \\
\hline GP-6-263R & 0.313 & 0.396 & $4.959 * *$ & 0.155 & 0.779 & 0.727 & $-0.148 *$ & $-2.962 * *$ & 0.056 & 1.066 \\
\hline GP-6-116R & 0.313 & 0.396 & 1.107 & 0.13 & 0.699 & -2.235 & $0.336 * *$ & $6.714 * *$ & -0.004 & $4.426 * *$ \\
\hline
\end{tabular}

** and * indicates significant at $1 \%$ and $5 \%$, respectively.

The parents were classified as good, average, and poor combiners based on the estimates of general combining ability effects. A summarized account of GCA effects of parents for different characters is presented in table 2 . None of the parental lines was found to be a good combiner for all the traits studied. General combining ability effects help to pinpoint the good parent. A perusal of GCA effects of ten parents (4 CMS lines and 6 testers) for 10 characters reveals that the CMS-249A was found to be a good general combiner for head diameter (0.684) and oil content (13.55),CMS-108A for days to $50 \%$ flowering (1.438), plant height(14.916), seed yield/plant (3.593) and volume weight (3.113)

$107 \mid 10-12$ | 2 
exhibiting significant GCA effects in a desirable direction. SimilarlyCMS-207A showed good general combining ability for seed yield/plant (3.199).

Among the male parents, IB-22R was found to be a good general combiner for seed yield/plant (2.548) and oil content (0.298). EC-198075 was a good general combiner for 100 seed weight (0.326) (Table 2).EC-601957 was found to be a good general combiner for plant height(-4.083). The male parent EC-178178 registered good general combining ability for oil content(0.589) whileGP-6-116 was a good general combiner for seed yield/plant
(6.714), 100 seed weight (0.336), and volume weight (4.426). The present results suggest that the parents viz., GP-6-116R, IB-22, and EC-178178R possessed high concentration of favorable genes for the respective traits and may be utilized in crossing programmes to develop the varieties/hybrids with desirable characteristics in sunflower. All these lines and testers can be exploited for the development of better hybrids and also in conventional breeding programmes. Such type of good general combiner for economic traits in sunflower was reported byPatil et al. (2012), and Qumar et al.(2015).

Table 3: Estimates of specific combining ability (SCA) effectsof crossesfor ten morphological traits in sunflower.

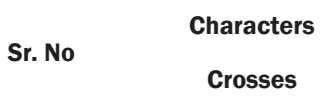

1 CMS-108A x IB-22R

2 CMS-108A x EC-601957R

CMS-108A x EC-198075R

4 CMS-108A x EC-178178R

5 CMS-108A $\times$ GP-6-263R

6 CMS-108A x GP-6-116R

7 CMS-250A x IB-22R

8 CMS-250A x EC-601957R

9 CMS-250A x EC-198075R

10 CMS-250A x EC-178178R

11 CMS-250A x GP-6-263R

12 CMS-250A x GP-6-116R

13 CMS-249A x IB-22R

14 CMS-249A xEC-601957R

15 CMS-249Ax EC-198075R

16 CMS-249A xEC-178178R

17 CMS-249A x GP-6-263R

18 CMS-249A x GP-6-116R

19 CMS-207A x IB-22R

20 CMS-207A xEC-601957R

21 CMS-207A xEC-198075R

22 CMS-207A xEC-178178R

23 CMS-207A xGP-6-263R

24 CMS-207A xGP-6-116R

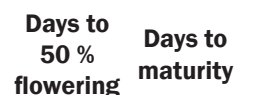

Plant height (cm)

1.896

-8.209 *

$-0.813 \quad-2.479$

5.333

$-1.188$

2.021

$-1.584$

$-0.063$

1.521

4.628

$-0.313$

0.271

$-1.209$

1.688

$-3.229$

1.041

$-1.313$

1.063

1.188

1.688

$0.313-4.313 *$

$-3.358$

$2.938 *-3.313-1.913$

$-1.813$

$-1.313$

$1.438-12.401 * *$

(1)

3.438

$-1.651$

$-0.646$

$-0.521$

$-6.181$

0.854

1.604

$-1.808$

2.979*

2.604

4.444

$-1.396$

$-0.896$

$-0.843$

$-0.146$

$-3.146$

6.819

$-1.646$

0.354

$-2.431$

1.271

$-2.438$

$-5.709$

$-1.229$

$-0.813$

$-0.167$

$-2.104$

$-0.313$

$-2.084$

$-1.479$

2.688

$-1.872$

2.271

1.38

6.791

1.271

$-0.563$

3.041

** and * indicates significant at $1 \%$ and $5 \%$, respectively.

In sunflower, negative SCA effects are considered to be desirable for days to $50 \%$ flowering, days to maturity, plant height, and hull content. Among 24 crosses, one hybrid for days to maturity, two

$\begin{array}{ccccccc}\begin{array}{c}\text { Head } \\ \text { diameter }\end{array} & \begin{array}{c}\text { Seed } \\ \text { filling }\end{array} & \begin{array}{c}\text { Hull } \\ \text { content }\end{array} & \begin{array}{c}100 \text { Seed } \\ \text { weight }(\mathrm{g})\end{array} & \begin{array}{c}\text { Seed } \\ \text { Yield / }\end{array} & \begin{array}{c}\text { Oil } \\ \text { content }\end{array} & \begin{array}{c}\text { Volume } \\ \text { weight }\end{array} \\ \begin{array}{ccc}(\mathrm{cm}) & (\%) & (\%)\end{array} & & (\%) & (\mathrm{g} / 100 \mathrm{ml})\end{array}$

$\begin{array}{llllll}-1.378 & 1.408 & 2.435 & 0.076 & -4.892 * * 1.510 * & -0.435\end{array}$

$\begin{array}{lllllll}0.824 & 2.141 & -1.0115 & -0.191 & 0.394 & -0.281 & -5.915 * *\end{array}$

$\begin{array}{lllllll}0.166 & -0.476 & -1.552 & 0.670 * * & -0.462 & -1.064 & 0.720\end{array}$

$\begin{array}{lllllll}-0.840 & -1.732 & -0.477 & 0.107 & -2.100 * & -1.031 & 3.964\end{array}$

$\begin{array}{lllllll}1.351 & 0.094 & 0.373 & -0.336 * & -0.382 & 0.353 & 0.179\end{array}$

$\begin{array}{lllllll}-0.124 & -1.436 & 0.235 & -0.325 * & 7.442 * * & 0.513 & 1.489\end{array}$

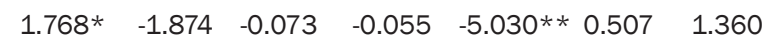

$\begin{array}{lllllll}-1.415 & 1.428 & -2.223 & 0.788 * * & 2.582 * & -0.449 & 2.690\end{array}$

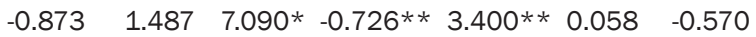

$\begin{array}{lllllll}0.831 & 0.196 & -0.485 & -0.196 & 4.263 * * & -0.074 & -2.031\end{array}$

$\begin{array}{lllllll}-0.968 & -1.128 & -3.985 & 0.533 * * & 1.480 & -0.926 & 0.914\end{array}$

$0.357-0.108-0.323-0.736 * *-6.696 * * 0.884-2.361$

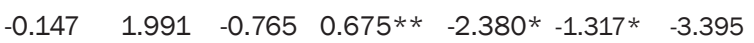

$\begin{array}{llllll}0.200 & -0.737 & 0.435 & -0.492 * * 2.836 * * & -0.739 & 0.245\end{array}$

$0.292-0.768-1.452-0.386 * 2.160 * 1.429 * \quad-1.375$

$\begin{array}{lllllll}-0.464 & 0.151 & 3.473 & -0.134 & 1.912 & 0.461 & 3.474\end{array}$

$\begin{array}{lllllll}-0.203 & 1.437 & -0.627 & -0.132 & 2.855 * * & 0.895 & 4.539 *\end{array}$

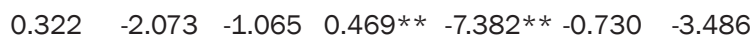

$\begin{array}{lllll}-0.244 & -1.524 & -1.598 & -0.696 * * & 12.302 * * \\ -0.700 & 2.471\end{array}$

$\begin{array}{lllll}0.392 & -2.832 & 2.802 & -0.104 & -5.812 * * 1.469 *\end{array} 2.981$

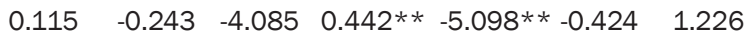

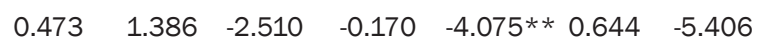

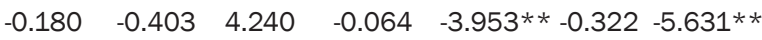

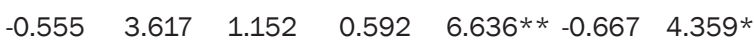

hybridsfor plant height and one hybrid for hull content registered high negative significant SCA effects. Similarly positive and significant SCA effects were recorded by one hybrid for head diameter, 
sevenhybrids for 100 seed weight, three hybridsfor oil content (\%), ninehybrids for seed yield per plant, and twohybrids for volume weight (g/100 mL) (Table 3).

The hybrid CMS-207A x GP-6-116R exhibiteda good SCA effect for 100 seed weight, volume weight, and seed yield/plant. CMS 249 x EC-198075 recorded significantSCA effect for oil content and seed yield/plant. The cross CMS-249A x GP-6-263 registered a good SCA effect for seed yield/plant and volume weight.The hybrid CMS-108A x IB-22 identified good SCA effects for days to $50 \%$ flowering, plant height, and seed yield/plant.

Table 4: Estimation of gene action (Var.gca and Var.sca) for ten morphological traitsin sunflower.

\begin{tabular}{lcccc}
\hline \multicolumn{1}{c}{ Characters } & Variance gca & Variance sca & Ratio Var.gca/ Var.sca & Gene action \\
\hline Days to $\mathbf{5 0}$ \% flowering & 0.1422 & 0.1353 & 1.0509 & Additive \\
Days to maturity & 0.4022 & $4.09301 *$ & 0.0982 & Non-additive \\
Plant height (cm) & 55.9036 & 49.0710 & 1.1392 & Additive \\
Head diameter (cm) & 0.0599 & 0.3671 & 0.1631 & Non- additive \\
Seed filling (\%) & $1.5773 * *$ & -3.1805 & -0.4959 & Non- additive \\
Hull content (\%) & $4.7644 * *$ & -0.8847 & -5.3853 & Additive \\
$\mathbf{1 0 0}$ - Seed weight (g) & -0.0286 & $0.3080 * *$ & -0.0928 & Non- additive \\
Seed Yield / plant (g) & $9.9669 * *$ & 36.7071 & 0.2715 & Non- additive \\
Oil content (\%) & $0.5424 * *$ & $0.7328 *$ & 0.7401 & Non- additive \\
Volume weight (g/100mL) & $5.1184 * *$ & $11.3085 * *$ & 0.4526 & Non- additive \\
\hline ** and *indicates significant at 1\% and 5\%, respectively. &
\end{tabular}

Cross CMS-250A x EC-198075 showedgood SCA effects for early days to maturity and seed yield/ plant.The hybrid CMS-250A x EC-601957 had good SCA effect for 100 seed weight and seed yield/plant. The cross CMS-250A x GP-6-263 was with good SCA effect for plant height and 100-seed weight. The crosses exhibiting higher per se performance and significant desirable SCA effects for various traits involved either good $x$ good, good $x$ average, good $x$ poor, average $x$ average, average $x$ good, poor $x$ good and poor $x$ average combining parents.

For all the traits under study, the crosses with significant SCA effects in the desirable direction involved parents with high $\mathrm{x}$ high, high $\mathrm{x}$ low or low $\mathrm{x}$ low GCA effect indicating that the high performance of these crosses was due to additive, dominance, and epistatic gene interaction. The ideal cross combination to be exploited is one whose high magnitude of SCA is present in addition to GCA in both or at least in one of the parents. Therefore, the hybrids CMS-207A x IB-22 and CMS-207A x GP6-116 for seed yield/plant and CMS-108A x IB-22 and CMS-207A x EC-601957 for oil content could be exploited through heterosis breeding. These results are in agreement with the findings of Chandra et al. (2011), Jondhale et al.(2012), Qamar et al.(2015), and Aleem et al.(2015).

The value of estimates of GCA and SCA variances, their ratios, and gene action is presented in table 4. It was observed that the magnitude of specific combining ability variances was larger than general combining ability variances for all characters except days to $50 \%$ flowering, plant height, seed filling (\%), and hull content (\%). The ratio of (ס2GCA/ס2SCA) was less than unity for all characters (except days to $50 \%$ flowering, plant height, and hull content (\%), indicating predominance of non-additive gene action. The ratio of GCA/SCA was less than 1 for days to maturity $(0.0982)$, head diameter $(\mathrm{cm})$ (0.1631), seed filling (\%) (0.4959), 100seed weight (g) (0.0928), oil content (\%) (0.7401), seed yield/ plant (g) (0.2715)and volume weight (g/100mL) $(0.4526)$ which indicated the presence of nonadditive gene action.

\section{CONCLUSION}

The crosses showing high desirable SCA effect have involved either one of the parents of high GCA effect and in turn, had high per se performance. The SCA effect of hybrids viz., CMS-250A x EC-198075 and CMS-249A x EC-198075 were highly significant for seed yield/plant (g) and other component traits in a desirable direction, indicating the high performance of these crosses is due to non-allelic gene action. The ratio of ( $\delta 2 \mathrm{GCA} / \delta 2 \mathrm{SCA})$ was less than unity for all characters except days to $50 \%$ flowering and plant height, indicating the additive type of gene action and predominance of nonadditive gene action for other studied traits. The hybrids viz., CMS-207A x IB-22 and CMS-108A x GP-6-116 recorded a high significant SCA effect for yield and yield components. Most of the crosses exhibiting high SCA effect involved either good $x$

$107 \mid 10-12$ | 4 
good oraverage $x$ good general combiners for the majority of the characters studied. The presence of additive or additive $x$ additive, additive $x$ dominance gene interaction effects would enhance the chance of crop improvement through simple selection. The prevalence of additive and non-additive genetic effects suggests the simultaneous exploitation of these gene actions by adopting selective intermating and recurrent selection. The parental lines 108A, 250A, IB-22, and EC-601957 have been identified as good general combiners and could be preferred in a breeding programme, as these parents upon crossing, are expected to give desirable segregants in the succeeding generations.

\section{REFERENCES}

Aleem, M.U., Hafeez, A.S., Saif-ul-Malook, Muhammad, A., Saeed, A. Q., Muhammad, Z.S. and Muhammad, A.H. (2015). Estimation of gene action for achene yield in sunflower (Helianthus annuus L.). AmericanEurasian J. Agric. \& Environ. Sci., 15(5): 727-732.

Chandra, B.S., Kumar, S., Ranganatha, A.R.G. and Dudhe, M.Y. (2011). Combining ability studies for development of new hybrids over environments in sunflower (Helianthus annuus L.). J. Agric. Sci., 3(2): 230.
Halaswamy, K.M., Channakrishnaiah K.M. and Kulkarni, R.S., (2004). Combining ability studies in sunflower (Helianthus annuus L.). Crop. Res. 28(1/3): 103112.

Jondhale, A.S., Goud, I.S. and Praveenkumar, B. (2012). Combining ability and gene action studies in diverse cms sources in sunflower (Helianthus annuus L.). Int. J. Sci. and Res., 3(3.358): 2183-2187.

Kempthorne, O., (1957). An Introduction of Genet. Stat., The lowa University Press.

Patil, R., Goud S., Kulkarni V. and Bankar C., (2012). Combining ability and gene action studies for seed yield and it's components in sunflower (Helianthus annuus L.). E.J. plant breeding3(3): 861-867.

Qumar, R., Hafeez, A.S., Amir, B. and Muhammad, H.N. Tahir. (2015). Estimation of combining abilities for early maturity, yield and oil related traits in sunflower (Helianthus annuus L.).I.J.S.N., 6 (1):110 -114.

Radhika, P., Jagadeshwar K. and Khan K.A., (2001). Heterosis and combining ability through line $x$ tester analysis in sunflower (Helianthus annuus L.). J. Res., ANGRAU29 (2-3): 35-43.

Ravi Rana, Sheoran R.K., Rakul Kumar and Gill, H.S., (2004). Combining ability analysis in sunflower (Helianthus annuus L.). Nation. J. of Plant Improv., 6(2): 89-93. 